\title{
Correction to: Investigation of Fluorine-18 Labelled Peptides for Binding to Cholecystokinin-2 Receptors with High Affinity
}

\author{
Naeem-UI-Haq Khan ${ }^{1,2} \cdot$ Alicia Corlett $^{3} \cdot$ Craig A. Hutton $^{1} \cdot$ Mohammad B. Haskali $^{2,4} \oplus$
}

Published online: 7 January 2022

(c) The Author(s) 2022

\section{Correction to: \\ International Journal of Peptide Research and \\ Therapeutics (2022) 28:6 \\ https://doi.org/10.1007/s10989-021-10310-z}

The original version of this article unfortunately contained typos in Keywords and Author contributions section. Also, the supplementary material had incorrect article title.

The first keyword should be Cholecystokinin-2 receptors instead of Cholecyctokinin-2 receptors. In Author Contributions section, the word assisted was misspelled as assited.

Also, the supplementary material was published with incorrect article title.

The original article has been corrected.

Supplementary Information The online version contains supplementary material available at https://doi.org/10.1007/s10989-021-10351-4.
Open Access This article is licensed under a Creative Commons Attribution 4.0 International License, which permits use, sharing, adaptation, distribution and reproduction in any medium or format, as long as you give appropriate credit to the original author(s) and the source, provide a link to the Creative Commons licence, and indicate if changes were made. The images or other third party material in this article are included in the article's Creative Commons licence, unless indicated otherwise in a credit line to the material. If material is not included in the article's Creative Commons licence and your intended use is not permitted by statutory regulation or exceeds the permitted use, you will need to obtain permission directly from the copyright holder. To view a copy of this licence, visit http://creativecommons.org/licenses/by/4.0/.

Publisher's Note Springer Nature remains neutral with regard to jurisdictional claims in published maps and institutional affiliations.

The original article can be found online at https://doi.org/10.1007/ s10989-021-10310-z.

Mohammad B. Haskali

mo.haskali@petermac.org

1 School of Chemistry, Bio21 Molecular Science and Biotechnology Institute, University of Melbourne, Melbourne, VIC 3010, Australia

2 Radiopharmaceuticals Research Laboratory, Peter MacCallum Cancer Centre, Melbourne, VIC, Australia

3 Department of Nuclear Medicine, The Royal Melbourne Hospital, Parkville, VIC 3000, Australia

4 Department of Oncology, Sir Peter MacCallum, The University of Melbourne, Melbourne, VIC 3010, Australia 